\title{
A STEP TOWARD ENLIGHTENED JUSTICE
}

\author{
GREGORY ZIIBOORG, M.D.†
}

I

7 He United STATes COURT OF APPEALS for the District of Columbia Circuit, speaking through the judicious and schol-

1 arly opinion of Judge Bazelon, has rendered a decision which is bound to cause rejoicing among many if not the majority of criminologists; and it is bound to create repercussions for a long time to come.

The decision appears disarmingly simple: the traditional right-andwrong test is finally disposed of with trenchant persuasiveness. The court boldly searches into the scientific literature of the day, i.e., forensic psychiatric literature; it does not hesitate to acknowledge the validity of clinical facts, even though these facts established by medical science do not seem to correspond to the older juridical definitions of the same clinical facts. The court endeavors, and not without some success, to establish some historical perspective with regard to the problem of insanity and criminal responsibility. In short, the heavy and at times stifling burden of the M'Naghten rule has been lifted, and the rule has been shown as not valid in the light of modern psychiatric knowledge.

One cannot help but feel that this historic decision is bound to become a point of departure for many an enlightened and creative decision on the part of both judges and juries who heretofore were manacled by a strange leftover of ancient prejudice couched in legalistic terms and meaning so little. How else can one characterize the M'Naghten rule and its older brother, the right-and-wrong test? I have said many times in public and in print, and I shall never tire of repeating, that it is only with regard to mental disease in a criminal case that the law assumes to dictate its formalistic views to medicine. There is no written or unwritten law which presumes to tell us what appendicitis is. The doctor's diagnosis in such a case is accepted, as well as the doctor's method of demonstrating how he made the diagnosis and how he confirmed it. There is not a lawyer in the world

+Practicing psychiatrist, author, and lecturer. 
who would challenge such a doctor by confronting him with a legal definition of appendicitis and forcing him to prove or disprove the presence or absence of legal appendicitis, regardless of the clinical, pathological condition known in medicine as appendicitis.

On the other hand, for centuries jurisprudence has claimed that it was able to make its own diagnosis of its own conception of so-called legal insanity, and by means of statutory formulas impose both the legal pseudo-diagnosis and the legalistic criteria upon the medical clinician who stands as witness.

From this angle the decision of the court of appeals in the Monte $W$. Durham case must be considered truly momentous, and Judge Bazelon's opinion a vital turning point in the history of forensic psychiatry. It is worth while to recall in this connection the passionate and almost deadly struggle of Cornelius Agrippa with the Court of the City of Metz in the twenties of the sixteenth century. Agrippa was a lawyer and a medical man, but the court had its own clinical definition which did violence both to medicine and justice. We might also recall with considerable benefit the violent and vituperative struggle of a generation after Agrippa, the struggle between the great lawyer Jean Bodin and the dedicated psychiatrist Johannes Weyer.

Judge Bazelon's opinion, viewed against the background of history, marks a turning point in a struggle which has been familiar to us for at least four hundred years. The dispassionate, quiet, judicious tone of Judge Bazelon's opinion might lead the uninitiated to the mistaken conclusion that it is really something simple and "natural"-something we might take for granted. Nothing would be more erroneous. From the historical point of view it is a bold, gigantic step in the direction of enlightened instead of formalistic justice, of humanism instead of bureaucratic obedience to a legal formula.

\section{II}

A critical evaluation of the decision under consideration must naturally be deferred. It all depends on how the lower courts learn to apply the principles of this decision, how the prosecuting and defending attorneys, who are all imbued with the formalistic, double psychiatric standards-clinical and legal-how they will learn to utilize this decision. However, one can foresee a few difficulties ahead which should not be overlooked.

Judge Bazelon's opinion, in which Judges Edgerton and Washington 
concurred, is in two parts. The first part concludes that judgment must be reversed and the case remanded for a new trial, because the trial judge, disregarding the whole evidence, had merely concluded that there "was no testimony concerning the mental state" of Durham on the date of July 13,1951. There is the rub. The opinion of the court of appeals rightly and eloquently calls the judge to task for not looking at the situation as a whole and seeing that the court was dealing with a mentally sick individual who had been sick for years and who could not therefore be "of sound mind" on July 13th; of unsound mind on July 12 th, and again of unsound mind on July 14th. There is something in this attitude that is both irrational and inhuman. A mental illness, a severe chronic mental illness, cannot be considered as something that enters and leaves a given person at various periods. A mental illness cannot be considered as something that, when it enters a person, makes him awfully ill, and when it leaves a person, leaves him unscathed, hail, hearty, completely and fully in possession of all his faculties of reason and will. Reason and will must function together; if they are separated be it ever so slightly we deal with serious mental pathology. Lawyers will have to learn something about the indivisibility of the human personality before they learn to apply Judge Bazelon's opinion judiciously and psychologically correctly.

The psychiatrist, too, will have to learn a great deal. For during the generations of practice of psychological errors by forensic psychiatrists, the psychiatrists, like the lawyers, became habituated to practice these errors with an air of unimpeachable respectability, and with a legal-scientific earnestness which wrapped the errors in a sort of blanket of correctness which is anything but correct.

Judge Bazelon quotes in part a statement of the acting superintendent of the mental hospital from which Durham was released in the custody of the District jail, stating that the accused was "mentally competent to stand trial . . . able to consult with counsel to properly assist in his own defense." This statement leaves entirely aside the fact that Durham appears to be a self-defeating, self-punishing, selfdestructive (he once tried suicide) individual, and therefore unable psychologically to act in his own behalf; for he who wishes unconsciously to destroy himself cannot consciously and effectively try to avoid punishment, or any suffering that fate might offer him. There

${ }^{1}$ Pp. 864-65. 
have been cases reported of people who sought by all means the penalty of death, and got it ultimately. But leaving aside this psychiatric aspect of the case, it is in my opinion not right for a clinical psychiatrist to express a purely juridical opinion. I doubt whether we psychiatrists are really competent to tell the court whether a given person can stand trial and consult counsel, etc. All we can do is to tell the court of the mental condition of the given case, and let the court decide. If psychiatrists insist that lawyers should not play the role of psychiatric clinicians, and if Judge Bazelon's opinion is to prevail that only sound clinical data as to mental illness in the psychiatric and not the old legal sense matter, it becomes incumbent upon the psychiatrist, even the forensic one, to stick to his clinical grindstone and not to trespass into the field of the law.

The second part of Judge Bazelon's opinion is by far the most important and decisive one. Disposing (and quite rightly) of the older principle of the irresistible impulse, which supplemented the M'Naghten rule in the District of Columbia, the opinion reads in part:

The rule we now hold must be applied on the retrial of this case and in future cases is not unlike that followed by the New Hampshire court since 1870. It is simply that an accused is not criminally responsible if his unlawful act was the product of mental disease or mental defect. ${ }^{2}$

\section{The opinion closes as follows:}

The legal and moral traditions of the western world require that those who, of their own free will and with evil intent (sometimes called mens rea), commit acts which violate the law, shall be criminally responsible for those acts. Our traditions also require that where such acts stem from and are the product of a mental disease or defect as those terms are used herein, moral blame shall not attach, and hence there will not be criminal responsibility. The rule we state in this opinion is designed to meet these requirements.

Reversed and remanded for a new trial. ${ }^{3}$

Seldom is history made with such unassuming quietness and almost self-effacing modesty, without loud headlines and without self-serving pronouncement. But this is great history in the making. This momentous step over the erstwhile impediment which was the $M^{\prime} N$ aghten rule will require many more "consolidating" steps. For the responsibility of the psychiatrist is greatly enhanced by this decision of the United States Court of Appeals. Before the courts learn to accept the data

2Pp. 874-75.

${ }^{3}$ P. 876. 
offered by modern clinical psychiatry, they are bound to try to pin the psychiatrist down to things to which one cannot pin anybody down. The trial judge in the Monte W. Durham case tried to pin Dr. Gilbert down on the issue of whether Durham's transgressions were a result of his mental illness. The answer to such a question in this case should have been a bold and unequivocal "Yes"-provided the court would not demand the impossible from the psychiatrist and insist that he produce "evidence" of how this particular act was the result of this particular illness. At times it is possible to demonstrate the intimate connection between the given clinical act and the given mental illnessat times it is not possible without careful, and protracted, study. The clinical judgment of the psychiatrist-provided he be properly qualified -must be accepted by the courts to the same extent as the clinical judgment of a surgeon or an internist.

Whatever the complexities and even the difficulties ahead as a result of this reversal of the lower court in the case of Monte W. Durham, both psychiatry and jurisprudence ought to be grateful for the enlightened courage of the three judges who were responsible for the new turn in our criminal jurisprudence. The great figure of Isaac Ray, whom the opinion quotes several times, stands out in even greater relief now, for it was Isaac Ray who proclaimed in 1838, in Maine and in New Hampshire, that which Judge Bazelon so quietly and so effectively stated on July 1, 1954. 